\title{
Danmarks bidrag i Arktis
}

Af Vittus QujaukitsoQ

Danmark har en vigtig rolle at spille i Arktis, ikke kun for varetagelsen af grønlandske interesser, men også for varetagelsen af danske interesser. Men for fuldt ud at kunne løfte opgaven og de udfordringer, som bliver større i disse år, er det nødvendigt at Danmark styrker de ressourcer, som afsættes til samarbejdet i Arktis, og opruster på den nødvendige viden om Grønland og arktiske forhold.

Grønland og Danmark har generelt et godt samarbejde om at varetage Grønlands og kongerigets samlede interesser udadtil. Men der er et væsentligt potentiale for at opnå mere indflydelse og bedre interessevaretagelse i forhold til tredjelande, hvis vi øger de ressourcer og den viden, som vi sammen mobiliserer til arbejdet.

Hvis Danmark skal kunne fylde mere i arbejdet i Arktis, er det først og fremmest vigtigt, at danske politikere og diplomater får bedre indsigt og grundlæggende kompetencer om rigsfællesskabets opbygning og ansvarsfordeling og de varierende interesser, der eksisterer i kongerigets forskellige rigsdele.

Der bliver i disse år taget vigtige skridt både fra dansk og grønlandsk side til at få et sådant tættere samarbejde etableret. Jeg blev sidste år indbudt til at tale på Udenrigsministeriets årlige ambassadørmøde, hvilket - kan man mene -utroligt nok ikke er sket for en grønlandsk minister før. Den dialog, koordinering og vidensudveksling, som er nødvendig, skal kontinuerligt udvikles og udbygges.

Det vil altid være vigtigt for Grønland at have en tæt dialog med den danske udenrigsminister og den danske erhvervs- og vækstminister. Det har været vigtigt for mig fra starten at få etableret et sådant tæt samarbejde, også efter den danske regerings tiltræedelse i 2015. At udenrigsminister Kristian Jensen er enig med mig i den prioritering, understreger for mig det tætte samarbejde, som Grønland og Danmark også bør have i de kommende år.

Nogle af de emner, som fyldte en del allerede i de første måneder af samarbejdet mellem mig og den danske udenrigsminister, var grønlandsk uraneksport, kontinentalsokkelprojektet og det fælles krav, vi har indgivet for området omkring nordpolen, kontraktudbuddet for Thule Air Base, forbedring af grønlandske produkters adgang til eksportmarkederne, samarbejdet i den internationale hvalfangstkommission IWC, samarbej-

Vittus Qujaukitsoq, Naalakkersuisoq (landsstyremedlem) for Erhverv, Arbejdsmarked, Handel og Udenrigsanliggender. 
det om EU-spørgsmål og samarbejdet i Arktisk Råd.

Denne korte liste siger lidt om, hvor bredt samarbejdet spænder - og det er kun et udpluk af de sager, som over det sidste halvandet år er blevet håndteret $\mathrm{i}$ samarbejde mellem det danske udenrigsministerium og mine embedsfolk.

For at illustrere væsentligheden af samarbejdet vil jeg kort beskrive nogle af Naalakkersuisuts - den grønlandske regerings - prioriteter og udfordringer i forhold til omverdenen, således som de ser ud fra Nuuk.

\section{Grønland i verdenssamfundet}

Grønlands økonomi er i disse år udsat for et demografisk pres, som er væsentligt kraftigere, end hvad vi ser i Danmark. En stor generation af ældre går snart på pension, og alt for mange unge i Grønland får forsat ingen kompetencegivende uddannelse. Desuden har der i de sidste mange år har været en nettoudvandring fra Grønland, så vi i dag har negativ befolkningstilvækst.

Den grønlandske økonomi har brug for reformer, og det grønlandske samfund har brug for udefrakommende investeringer, der kan skabe rammer for fremtidig vækst og indtjening.

Det er derfor vigtigt for den grønlandske regering at sikre, at andre landes interesse for Grønland og Arktis i endnu større omfang omsættes til økonomiske muligheder. Jeg har som minister stillet mig i spidsen for indsatsen for at forstærke og vedligeholde denne positive opmærksomhed. I vores arbejde hen imod en selvbåren og flerstrenget økonomi, som har opbakning blandt alle de grønlandske partier, bevæger Naalakkersuisuts fokus sig derfor mere og mere imod handel og de generelle rammebetingelser for økonomisk samarbejde med andre lande.

I 2015 tog Lars Løkke Rasmussen initiativ til at nedsætte en arbejdsgruppe, der skal genoverveje hele den danske udenrigstjenestes politiske prioriteringer. Det er et arbejde vi i Grønland har budt velkommen, særligt da en af de grundlæggende præmisser for arbejdsgruppens formål synes at være, at der fra dansk side skal lægges betydeligt flere kræfter i at løfte Danmarks ansvar i Arktis.

\section{Erhverv, handel og told}

Grønlandske og færøske virksomheder fik i 2015 adgang til statens finansieringsfond, Vækstfonden. Det var en vigtig beslutning, som vil skabe grundlag for yderligere aktiviteter for små og mellemstore grønlandske virksomheder. Herudover fik vi sikret, at Grønland blev omfattet af Eksportkreditfondens udstedelse af garantier, således at kreditværdige grønlandske erhvervsprojekter også har adgang til disse faciliteter. Jeg arbejder samtidig på at sikre forbedrede finansieringsmuligheder for Grønlands erhvervsudvikling i Den Nordiske Investeringsbank og Den Europæiske Investeringsbank.

Fiskeriet er fortsat Grønlands største og vigtigste erhverv, hvor en vigtig del af værdiskabelsen og langt hovedparten af eksporten finder sted. Handelsfremme er derfor en vigtig komponent i sikringen af, at Grønland bliver mere økonomisk selvbårent, og Naalakkersuisut prioriterer dette højt.

Japan, Kina, Sydkorea og andre asiatiske lande er identificeret af vores fiskeriindustri som prioriterede markeder (ud over det europæiske). De udgør store, 
købestærke markeder for vores eksport. Det er derfor, at jeg i oktober 2015 og marts 2016 valgte at stå i spidsen for vigtige grønlandske erhvervsfremstød i Kina og Sydkorea. Det stigende antal handelsaftaler mellem Grønlands væsentligste markeder og konkurrenter er problematiske for Grønlands konkurrenceevne, idet Grønland eksempelvis står uden for EU-Canada frihandelsaftalen. Det samme vil være tilfældet for de kommende EU-Japan og EU-USA-aftaler, der er under forhandling.

Grønlandske fiskeriprodukter har haft toldfri adgang til EU's markeder siden 1985 under Grønland-EU fiskeriaftalen, men værdien af vores toldfri adgang udhules i takt med, at EU indgår yderligere frihandelsaftaler med konkurrerende økonomier.

Naalakkersuisut gennemfører derfor nu en grundig analyse af markedsadgangen til vores afsætningsmarkeder. Analysearbejdet, som forventes tilendebragt $i$ år, vil give et retvisende billede af de væsentligste toldbarrierer fra tredjelande, der udfordrer vores primære fiskerieksportprodukter, og det vil danne basis for indledning af egentlige toldforhandlinger. Grønland er nemlig et selvstændigt toldområde. Også her er der et tæt og meget værdsat samarbejde med det danske udenrigsministeriums handelspolitiske kontor. Handelsarbejdet er et godt sted for Danmark og Grønland at samarbejde, og vi gør det allerede.

\section{Samarbejdet med danske ambassader}

I det daglige har vi et tæt samarbejde med de danske ambassader. Ambassaderne er hele kongerigets ambassader, og de danske ambassadører er også Grønlands ambassadører.
Grønland har selv egne repræsentationer i Bruxelles og i Washington, D.C. Begge ligger sammen med eller ved siden af den danske ambassade/EU-repræsentation, og samarbejdet med de danske kollegaer er tæt. Det var ud fra en strategisk tilgang, hvor der blev lagt stor vægt på Grønlands erhvervsinteresser og skabelse af arbejdspladser i Grønland, at Naalakkersuisut i 2014 åbnede sin anden repræsentation i udlandet i Washington, D.C., og at Island i 2013 besluttede at åbne et generalkonsulat i Grønland. Denne proces forventes fortsat.

Grønlands repræsentation i Washington, som både er akkrediteret USA og Canada, er under fortsat opbygning særligt for at fremme eksport og tiltrække investeringer fra USA og Canada. Repræsentationen i Bruxelles, som blev oprettet i 1992, varetager især Grønlands økonomiske interesser ved EU's institutioner.

Grønland har væsentlige interesser i forholdet til EU, hvor Grønland har partnerskabs- og fiskeriaftaler. Værdien af EU Partnerskabsaftalen alene udgør cirka 1,6 milliarder kroner for Grønland for perioden 2014-2020. Desuden skal man erindre, at Grønland er det eneste OLTland (EU's Oversøiske Lande og Territorier), som har en egentlig finansiel ramme afsat.

Grønlands tilstedeværelse i Bruxelles overflødiggør ikke Danmarks varetagelse af kongerigets samlede interesser over for EU. Snarere tværtimod. Siden $1992 \mathrm{er}$ der udviklet en klar arbejdsdeling, som giver resultater både for Grønland og for Danmark i forhold til den arktiske dagsorden.

Det samme gælder Grønlands tilstedeværelse i Washington, hvor vores repræ- 
sentation på ingen måde kan erstatte den danske ambassade. Ambassaden i Washington har især haft en vigtig rolle for Grønland i kraft af Danmark/Grønlands forsvarssamarbejde med USA.

Med Itilleq-erklæringen fra 2003 og Selvstyreloven fra 2009 er Danmark blevet forpligtet til fuldt ud at inddrage Grønland, når udenrigs- og sikkerhedspolitiske spørgsmål af betydning for Grønland drøftes. Det gælder særligt i relation til USA's militære tilstedeværelse i Grønland. Etableringen af Grønlands repræsentation i Washington var nødvendig for at sikre, at denne inddragelse i praksis finder sted på en effektiv og fleksibel måde.

\section{Rigsfællesskab og rollefordeling}

Rigsfællesskabet er en helt særlig konstruktion internationalt, og mange steder i verden er der konstant behov for at forklare, hvad Kongeriget Danmark er. Vi er jo et 'commonwealth' bestående af tre rigsdele, men ikke på samme måde som det britiske commonwealth var det. Danmark og Grønland er tæt forbundne og dog med separate kompetencer, myndigheder og demokratiske institutioner.

Selvstyreloven og Itilleq-erklæringen sætter rammerne eller 'spillereglerne’ for hvem der gør hvad, også i relation til tredjelande. Som hovedregel taler og forhandler Grønland på egne vegne, når det drejer sig om fuldt hjemtagne områder. Disse spilleregler kan være en udfordring at forklare udadtil. Det har bl.a. i de senere år været en udfordring i Arktisk Råd og kan også være det $\mathrm{i}$ forhold til USA på forsvarsområdet. Men takket være en stor fælles indsats, ikke mindst siden 2013, er det lykkedes at skabe forståelse for de helt særlige rammer, der gælder for kongerigets deltagelse i internationale aktiviteter.

Grønland er i FN-sammenhænge en forhenværende koloni befolket af et oprindeligt folk. Danmark og Grønlands forhold i dag er unikt - ikke kun i Arktis, men også globalt. Det bør vi være stolte af både i Grønland og i Danmark. Danmark og Grønland har på mange måder været foregangslande for udviklingen internationalt. Med et tæt samarbejde imellem København og Nuuk bliver vores unikke sammensætning til en styrke.

\section{Grønland, Arktis og klima- forandringerne}

Sidste år deltog jeg sammen med Kristian Jensen ved USA's Arktiske Ministermøde i Anchorage i Alaska, som Præsident Obama var vært for. Vi havde sammen forberedt en fælles platform for vores deltagelse med koordinerede indlæg og trilaterale møder, hvor det var relevant, om Grønland og arktiske emner af relevans for både Grønland og Danmark.

De globale klimaændringer skaber allerede store synlige og målbare effekter i vores arktiske miljø. Det påvirker vores levevis både positivt og negativt. Det var derfor, at jeg sammen med den forrige danske udenrigsminister i marts 2015 var vært for et besøg af den franske udenrigsminister i Ilulissat i Vestgrønland. Her fik vi skabt øget opmærksomhed om klimaforandringernes enorme konsekvenser såvel i Grønland som i resten af verden. Besøget fulgte et lignende fælles dansk-grønlandsk initiativ i 2014, hvor vi havde FN's generalsekretær Ban $\mathrm{Ki}$-moon på besøg. Begge besøg spillede en væsentlig rolle i FN's og Frankrigs 
forberedelser til det vellykkede klimatopmøde i Paris i december 2015.

Det er vigtigt at erindre, at Grønland og den grønlandske natur ikke er et museum indrettet med henblik på at sikre en verdensarv for turister og miljøinteresserede fra andre dele af verden. Det grønlandske samfund har bestået i årtusinder, i tæt samspil med den natur som de grønlandske fangere og fiskere lever med og i. Grønland er under udvikling, men det glemmes af og til, når der tales klimaudfordringer i Arktis. Der bor og har altid boet mennesker i Arktis. Det er vores hjem.

Når klima- og miljøudfordringer, som er skabt af verdens industrialiserede lande, skal løses, er det vigtigt for Grønland, at der findes løsninger, som ikke udelukkende begrænser lande, som kun i meget ringe grad har gennemlevet en økonomisk udvikling, eller som indtil fornylig har været fastholdt i en kolonistatus.

Den grønlandske regering arbejder kontinuerligt for at sikre velstand og velfærd for det grønlandske samfunds borgere. Naalakkersuisut arbejder derfor aktivt for at sikre langsigtet erhvervsudvikling i Grønland. Denne udvikling kan betyde øget udledning af drivhusgasser $\mathrm{i}$ fremtiden. Man skal huske på, at Grønlands offentlige budget stadig for ca. 40 pct's vedkommende udgøres af et bloktilskud fra Danmark. Et bloktilskud, som både grønlandske og danske politikere over en årrække ønsker erstattet af reel økonomisk aktivitet i Grønland. En sådan økonomisk aktivitet vil ikke ligesom bloktilskuddet være CO2-neutralt.

Grønland er inden for vandkraft gået foran Danmark og det meste af resten af verden. Over 70 pct. af Nukissiorfiits Grønlands offentlige energiforsyningssel- skabs - samlede afsætning af el og varme er i dag genereret af 100 pct. vedvarende energi fra vandkraft.

Naturen er vigtig for os i Grønland. Vi lever tættere på og med naturen end næsten alle andre lande i verden. Vi er afhængige af fangst, fiskeri og vejret i vores daglige arbejde. Bæredygtig udvikling og den respekt for naturen, som man i andre lande - også i Europa - er begyndt at italesætte, har vi længe haft i Grønland, og den bør ikke nu påklistres vores levevis. Bæredygtighed har været et grundvilkår for grønlænderes omgang med naturen i årtusinder. Det er derfor, at miljøhensyn har førsteprioritet i vores energipolitik og erhvervsudviklingsplaner.

Interessen for at bevare og beskytte havmiljøet har været kraftigt stigende igennem en årrække, både globalt og regionalt, og særligt i forhold til Arktis fra lande og NGO'er uden for Arktis. Det ses $i$ en række internationale fora som Grønland indgår $i$, herunder Konventionen om beskyttelse af havmiljøet i nordøst Atlanten (OSPAR) og Arktisk Råd, hvor en række anbefalinger peger på behovet for at fremme beskyttelsen af vigtige biologiske marine ressourcer. I disse fora er der i de senere år opstået mærkbar interesse for beskyttelses- og forvaltningsmæssige tiltag over for områder i internationalt farvand, herunder Det Arktiske Ocean.

Et af de instrumenter, som er foreslået til beskyttelse og bæredygtig udnyttelse af biologiske ressourcer, er etableringen af marine beskyttede områder eller reservater. Grønland er selvfølgelig enig i, at beskyttede områder kan være med til at sikre specifikke arter eller vigtige økosystemer, men debatten om denne type fredningsinitiativer skygger desvær- 
re fuldstændigt for de reelle miljøudfordringer i Arktis.

Virkeligheden er, at havressourcerne og miljøet i og omkring Grønland og i resten af Arktis i dag påvirkes massivt af industrielle aktiviteter langt fra Arktis - særligt i Europa og Asien. Bæredygtig fangst og fiskeri og den meget begrænsede industrielle udvikling, som er undervejs i Grønland, spiller i denne sammenhæng ingen rolle.

De havpattedyr, som vi grønlændere lever af, og som vi har drevet bæredygtig jagt på i årtusinder, er i dag fyldt med giftstoffer fra industrier i andre dele af verden - fjernt fra Arktis. I Grønland advarer lægerne i dag om, at havpattedyr kun bør indtages i et meget begrænset omfang, da giftstofferne forbliver i menneskekroppen hele livet og giver risici for fødselsskader, kræft og andre sygdomme.

Grønland støtter det globale samarbejde om bedre beskyttelse af havmiljøet, der blandt andet arbejdes med under Biodiversitetskonventionen og OSPAR, men det er vigtigt, at de rigtige virkemidler benyttes. Der opretholdes ikke balance ved at afskære mennesker i Arktis fra deres allerede hårdt pressede og legitime ret til at leve i og med naturen. Der må og skal skrides ind over for de store globale udledere af forurening, således at vores natur og levevis kan bevares også for kommende generationer.

\section{Arktisk råd og interessen fra Asien}

Oprindeligt blev Arktisk Råds ministermøder afholdt hvert andet år, typisk med deltagelse af de otte arktiske staters miljøministre. Fra Danmark/Grønland deltog sædvanligvis en minister fra enten Danmark eller Grønland på vores fælles vegne. I dag er der efterspørgsel ef- ter pladserne på en helt anden vis, og de emner som diskuteres i Arktisk Råd vedrører i dag alle aspekter af vores liv som borgere i Grønland. Derfor skaber det til tider frustration, at der ikke altid er forståelse for, at den ret, Selvstyreloven giver Grønland til at repræsentere sig selv udadtil på fuldt overtagne sagsområder, er vigtig for at sikre en ordentlig varetagelse af vores interesser. Der står meget på spil for Grønland. Arktisk Råd er vores primære regionale samarbejdsorgan med vores nærmeste naboer.

I dag deltager samtlige udenrigsministre ved Arktisk Råds ministermøder, og nye lande står i $k \varnothing$ for at blive anerkendt som observatører, og nogle - som EU får afslag. Der er stor interesse fra Asien, særligt fra Kina, Japan og Sydkorea, og det er ikke akademisk interesse. Det handler om langsigtet økonomisk interesse for regionen. For vores olie, vores mineraler, søruter, infrastruktur, fiskeri og forskning.

Hvis udviklingen skal være til gavn for Grønland - for Grønlands minesektor og fiskeri - kræver det en meget væsentlig international indsats. Inden for minesektoren for at sikre opmærksomhed og investeringer og inden for fiskeriet for at sikre nye og bedre internationale rammebetingelser for eksport og for vores deltagelse i fiskeriet ud for vore kyster og delte havområder.

I juli 2015 indgik Grønland med de fire andre arktiske stater med kyst mod Det Arktiske Ocean en 'Erklæring om Fiskeri i Det Arktiske Ocean' med det formål at beskytte oceanet imod ureguleret fiskeri. Erklæringen er et vigtigt skridt frem mod en internationalt bindende aftale om fiskeri i den arktiske højsø, der kan forhindre ureguleret og ulovligt fiskeri i 
Det Arktiske Ocean. Processen følges tæt af fiskerinationer uden for Arktis, herunder i Asien. Deklarationen blev forhandlet og indgået af grønlandske forhandlere, først og fremmest på et møde i Nuuk i 2014, hvor deklarationen blev færdigforhandlet.

\section{Ny grønlandsk tilgang til samarbejdet}

De mange nye fælles initiativer imellem Danmark og Grønland, særligt siden 2013, er udtryk for en ny tilgang fra Grønlands side, der er ved at blive til normalen. Siden 2013 er der blevet afholdt trilaterale møder mellem Danmark/Grønland med udenrigsministre fra Canada, Japan og senest sidste år med Koreas udenrigsminister vedrørende arktiske og grønlandske emner af fælles relevans.

Selvstyreloven af 2009 er i sig selv meget vidtrækkende, og Grønland kan i dag fuldstændig legitimt forhandle aftaler med andre lande på langt de fleste områder helt uafhængigt af Danmark. Men der er fordele for både Danmark og Grønland ved en fælles tilgang. For Danmark betyder det, at der ikke skabes tvivl om, at ansvaret for udenrigs- og sikkerhedspolitikken for kongeriget formelt fortsat ligger i Danmark. For Grønland betyder en fælles dansk-grønlandsk tilgang, at vi eliminerer den tvivl som i nogen grad kan være til stede særligt hos lande i Asien om rigsfællesskabets sammensætning og kompetencefordeling. Grønland har formelt kompetencen - også i forhold til tredjelande - når det kommer til investeringer, erhverv, handel, toldsatser, forskning, osv., men for at opnå økonomisk fordelagtige aftaler for Grønland kan det være gavnligt, at Danmark indgår i drøftelserne som brobygger og ambassadør.

\section{Hvad kan Danmark bidrage med?}

I de kommende år håber jeg at se flere fælles dansk-grønlandske eksportog erhvervsfremstød, et mere udbygget dansk-grønlandsk samarbejde om informationsudveksling på udenrigsområdet, åbning af yderligere udenlandske repræsentationer i Nuuk, samt udbyggelse af den grønlandske udenrigstjeneste med yderligere en eller to repræsentationer i udlandet.

Endelig håber jeg, at det danske udenrigsministerium i langt højere grad vil drage nytte af de erfaringer og den viden, som er opbygget i Grønland.

Hvis Danmark og Grønland skal stå stærkere i Arktis, skal man holde op med at se på samarbejdet mellem Danmark og Grønland som en konkurrence mellem to parter, der hver især har behov for at markere sig på områder, hvor de mener at have særlige interesser/rettigheder. For at vi sammen skal have en styrke og en politik, som reelt kan udøve indflydelse blandt vore arktiske naboer, skal der i højere grad fokuseres på de styrker, som vi samlet set har til rådighed. Man skal huske på, at det i væsentlig udstrækning er kongerigets arktiske naboskab med stater som USA, Rusland og Canada, der gør Danmark til mere end et lille nordeuropæisk land uden egentlig geostrategisk betydning for store lande.

I de tilfælde hvor kommunikation mellem Danmark og Grønland på udenrigsområdet går galt, kan det få betydelige omkostninger ikke blot for Grønlands økonomiske relationer med andre lande, men så sandelig også for Danmarks troværdighed som en partner, der kan regnes med på højt internationalt plan.

I den konstruktion som er Danmark/ Grønland i Arktis, vil jeg særligt pege på, 
at Danmark nu i to omgange har udpeget en arktisk ambassadør. Det er der intet galt i. Den arktiske ambassadør kan have en vigtig funktion og - hvis funktionen bruges rigtigt - tilføre samarbejdet betydelig smidighed og effektivitet. Men det er i min optik besynderligt, at man ikke fra dansk side på noget tidspunkt har overvejet at tildele en grønlænder posten.

Nogle gange er det som om, at den arktiske region, som Grønland er en del af, og som Danmark ikke er en del af, gøres til noget andet, end det i virkeligheden er. Hvis Danmarks ambitioner om at blive taget alvorligt som en 'arktisk stormagt', således som Taksøe-Jensen i sit foreløbige udredningsarbejde pegede på, så bliver man i langt højere grad fra dansk side nødt til at anerkende Grønland som den arktiske rigsdel Grønland er, med egne interesser, ressourcer, kompetencer og historisk viden. Det er nu engang sådan verden, geografien og vores fælles historie er skruet sammen.

Der er rigeligt med udfordringer i Arktis, både for Danmark og Grønland. Jeg er optimist. Jeg mener, at vi mellem Danmark og Grønland nok skal finde frem til pragmatiske modeller for, hvordan vi bedst fremmer vores fælles interesser. Det er lykkedes for os hidtil. 